\title{
PRODUCTION OF GLUCOSE BY STARCH AND CELLULOSE ACID HYDROLYSIS AND ITS USE AS A FUEL IN LOW-TEMPERATURE DIRECT-MODE FUEL CELLS
}

\author{
J.-P. Spets ${ }^{1, a}$, M. Kuosa ${ }^{1, b}$, T. Granström ${ }^{2, c}$, Y. Kiros ${ }^{3 . d}$, J. Rantanen ${ }^{4, e}$, \\ M. J. Lampinen ${ }^{1, f}$, K. Saari ${ }^{1, g}$ \\ ${ }^{1}$ Helsinki University of Technology, Energy Technology, P.O. Box 4400, FI-02150 TKK, Finland. \\ ${ }^{2}$ Helsinki University of Technology, Biotechnology and Chemistry, P.O. Box 6100, FI-02150 TKK, \\ Finland. \\ ${ }^{3}$ Royal Institute of Technology, KTH, Dept. of Chem. Eng. and Technology, S100-44 Stockholm, \\ Sweden \\ ${ }^{4}$ Oy Hydrocell Ltd, Minkkikatu 1-3, FI-04430 Järvenpää, Finland \\ a jukka-pekka.spets@tkk.fi, ${ }^{b}$ maunu.kuosa@tkk.fi, ${ }^{c}$ tom.granstrom@tkk.fi, ${ }^{d}$ yohannes@kth.se, \\ ejyri.rantanen@hydrocell.fi, ${ }^{\dagger}$ markku.lampinen@tkk.fi, ${ }^{9}$ kari.saari@tkk.fi
}

\begin{abstract}
The use of glucose, which is produced from the acid hydrolysis of starch and cellulose, is studied as a fuel in a low-temperature direct-mode fuel cell (LTDMFC) with an alkaline electrolyte. Glucose is regarded as being as good a fuel as bioethanol, because both the fuels give 2 electrons per molecule in the fuel cell without carbonisation problems. However, glucose can be produced with fewer processing stages from starch and cellulose than can bioethanol. In the LTDMFC the fuel and the electrolyte are mixed with each other and the fuel cell is equipped only with metal catalysts. Cellulose as a fuel is of great importance because the fuel for the energy production is not taken from food production. A description of an acid hydrolysis method for starch and cellulose is presented. Values for glucose concentrations in each hydrolysate are analysed by means of a chromatographic method. Each glucose hydrolysate was made alkaline by adding of potassium hydroxide before feed in the fuel cell. Polarisation curves were measured, and they were found to produce lower current density values when compared to earlier tests with pure glucose. The Coulombic efficiency of pure glucose electrochemical oxidation in LTDMFC, which was calculated from a ratio of detected current capacity (As) to the maximum current capacity with the release of two electrons per molecule, was also found to be very low. Concerning the hydrolysates, the glucose concentrations were found to have values that were too low when compared to the earlier tests with pure glucose in a concentration of $1 \mathrm{M}$. The further development demands for the system under consideration are indicated. The concentration of glucose in the hydrolysate is essential to achieve high enough current density values in the LTDMFC.
\end{abstract}

Keywords: Direct mode fuel cell, low temperature, glucose, cellulose, acid hydrolysis

\section{Introduction}

The ideal fuel for low-temperature fuel cells in power generation systems would be a directly used fuel in a liquid phase, which allows the fuel to be stored and used more easily than gaseous hydrogen does [1, 2]. There are fuel cells which operate with solidphase electrolyte and tissue cultures, which contain a biological electro-catalyst either in the form of enzymes or of living microorganisms, together with proton-selective membranes for the in situ reforming of bioorganic materials [3-5]. However, fuels such as glucose or other carbohydrates can easily be utilised by mixing them directly in the electrolyte without the use of any auxiliary equipment or additional microbial cultures. Many studies have been conducted in which metallic catalysts were used in electrolytes with different $\mathrm{pH}$ values [1-11].

As far as glucose is concerned, the oxidation reactions take place with a yield of only two electrons per one molecule from 24 available electrons [10]. This yield is equal to aqueous bioethanol, when it is used as a fuel without carbonisation problems in the fuel cells $[6,7]$. In the earlier studies regarding direct bioorganic oxidations, the anodic 
catalyst materials were different $\mathrm{Pt}$ alloys [4-11].

\section{Bioorganic material as a fuel source}

In this study, a low-temperature direct-mode fuel cell (LTDMFC) in which a fuel and an aqueous electrolyte are mixed with each others is tested. The fuel is glucose $\left[\mathrm{C}_{6} \mathrm{H}_{12} \mathrm{O}_{6}\right]$ (as monosaccharide), which is of great importance, because it can be produced by acid catalytic hydrolysis at temperatures between 150 and $250{ }^{\circ} \mathrm{C}$ from starch $\left[\mathrm{C}_{12} \mathrm{H}_{10} \mathrm{O}_{10}\right]_{\mathrm{n}}$ and cellulose $\left[\mathrm{C}_{6} \mathrm{H}_{10} \mathrm{O}_{5}\right]_{\mathrm{n}}$ (as polysaccharides) according to the Equation (1) for starch [12-14]:

$$
\left[\mathrm{C}_{12} \mathrm{H}_{20} \mathrm{O}_{10}\right]_{n} \stackrel{+2 n \mathrm{H}_{2} \mathrm{O}, \mathrm{cat} \mathrm{H}^{+}}{\longrightarrow} 2 \mathrm{nC}_{6} \mathrm{H}_{12} \mathrm{O}_{6}
$$

The average cellulose content in different wood species (spruce, pine and birch) varies between values of 33 and $51 \%$ [15]. It is possible to reach up to a $90 \%$ yield of glucose, depending on the wood species, the concentration of acid, and the process temperatures [14]. However, highly concentrated acids and the process temperatures cause difficult corrosion problems in the process equipment. The principal flow sheet for the acid hydrolysation of polysaccharides is shown in Figure 1.

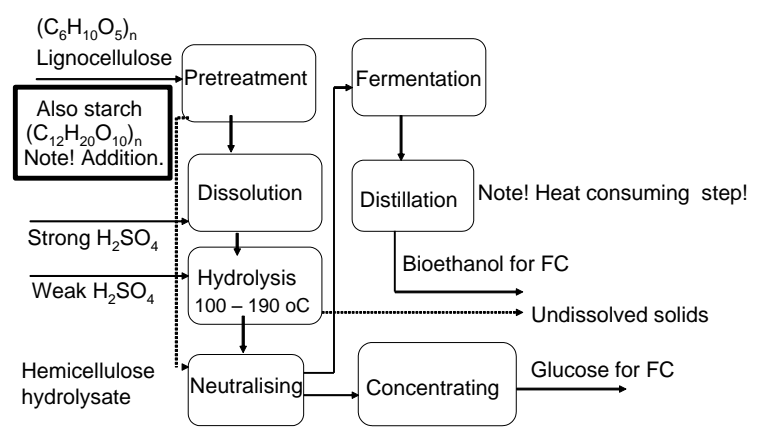

Figure. 1. Principal flowsheet of the acid hydrolysation process applied from Ref. [14].

From Figure 1 it can be seen that the undissolved solids from the hydrolysis stage can be fed to the combustion stage. When the heat production of the combustion stage is taken into account, the heat balance for glucose production is positive, whereas the heat balance for ethanol production is negative because of the heat-consuming concentration [16]. In the development of the direct-mode bioorganic fuel cell, the target is to increase the ionic oxidation reactions in the liquid phase. This would make possible a high electronic yield and electric power production from one bioorganic molecule. In this study, an anode catalyst of alloyed platinum with palladium (Pt-Pd) and a combined cathode catalyst of cobalt porphyrin complex (CoTPP) and of spinel $\left(\mathrm{MnCo}_{2} \mathrm{O}_{4}\right)$ are tested in the test fuel cell with an alkaline electrolyte. It was reported earlier that several electro catalysts can not work well in near-neutral-state electrolytes (at $\mathrm{pH}$ 7.4) because of low electric conductivity values [17].

\section{Experimental}

Test equipment. The test equipment included an LTDMFC (developed by Hydrocell), a recirculation pump (capacity $100 \mathrm{ml} / \mathrm{min}$ ), an air fan (i.e. a PC cooling fan) and a recirculation tank for the fuel electrolyte solution. The system also included a heating system (water bath) for the solution, but it was not used in these tests. The test fuel cell system is shown in Figure 2. The test fuel cell consisted of a two-cylinder structure. The inner cylinder was an anode electrode (Pt-Pd catalyst) and the outer one was a cathode electrode (combined $\mathrm{MnCo}_{2} \mathrm{O}_{4}$ and CoTPP catalysts). The anode catalyst structure was wetted on both sides of its surfaces. The distance between the anode and cathode was $1 \mathrm{~mm}$. The catalyst loadings of the anode electrode were $2.46 \mathrm{mgcm}^{-2}$ for both the $\mathrm{Pt}$ and $\mathrm{Pd}$ in the bimetallic combination (in a weight ratio of 1 to 1) with concentrations of $10 \%$ on carbon. The catalyst loadings of the combined cathode electrode contained a catalyst loading of $3.15 \mathrm{mgcm}^{-2}$ of CoTPP with a concentration of $18 \%$ on carbon and of $17.5 \mathrm{mgcm}^{-2}$ of $\mathrm{MnCo}_{2} \mathrm{O}_{4}$. The anode electrode consisted of a single-layer structure without diffusion material. The cathode electrode was of the double-layer type and contained both the active (catalyst) and the diffusion layers. The electrodes were sintered 
at a temperature of $350{ }^{\circ} \mathrm{C}$. The geometric areas of both electrodes were $200 \mathrm{~cm}^{2}$. The $\mathrm{Pt}-\mathrm{Pd}$ catalyst was a commercial grade from Johnson-Matthey. The CoTPP and the $\mathrm{MnCo}_{2} \mathrm{O}_{4}$ catalysts were commercial products from Oy Hydrocell Ltd.

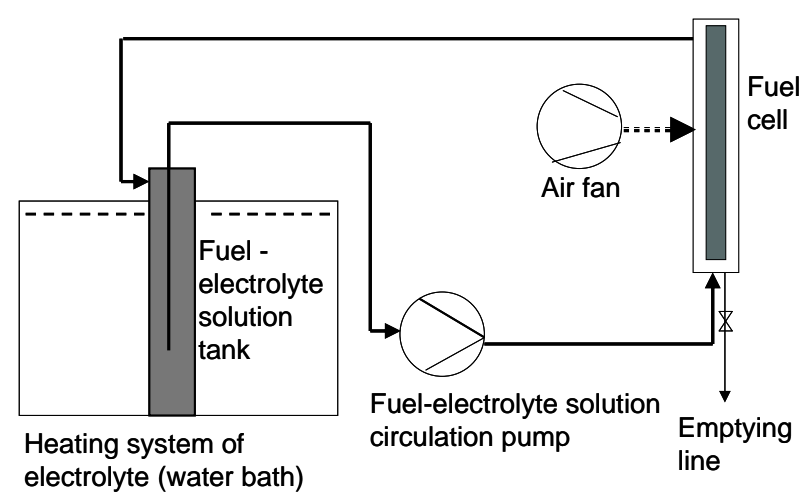

Figure 2. Test fuel cell equipment.

The current and voltage values were measured with Fluke 43 and Fluke 73 measurements, respectively. A Velleman PS 613 (Dc) device was used as a resistor $[1,2]$.

Acid hydrolysation. Maize starch was used in starch hydrolysis experiments at a temperature of $132{ }^{\circ} \mathrm{C}$ according to Ref. [13]. Because of the larger volumes $\left(10 \mathrm{dm}^{3}\right)$ the time of hydrolysis was extended to 80120 min compared to the 40 minutes used in the Ref. [13]. White cellulose paper was weighed and dissolved in $72 \% \mathrm{H}_{2} \mathrm{SO}_{4}$ for one hour at room temperature (RT) to bring the cellulose into solution, followed by diluting the solution to $4 \% \quad \mathrm{H}_{2} \mathrm{SO}_{4}$ and then autoclaving the solution at $121{ }^{\circ} \mathrm{C}$ for one hour to depolymerise the cellulose to glucose. The glucose content was determined by using an Aminex HPX-87P column (Bio-Rad) at $70{ }^{\circ} \mathrm{C}$ with distilled water as the mobile phase at an elution rate of $0.6 \mathrm{ml}$ min-1. All components were analysed with a refractive index (RI) detector.

Test routine in fuel cell equipment. The test routine in all the tests was as follows: 1. Preparation of an aqueous alkaline electrolyte of $2 \mathrm{M}\left(\mathrm{mol} \mathrm{dm}^{-3}\right)$ potassium hydroxide ( $\mathrm{KOH}$ by Sigma Aldrich) in each hydrolysate from acid hydrolysation. 2. Addition of the electrolyte fuel solution in the fuel cell and starting the air fan. 3 . Measurement of the open circuit voltage (OCV) generation of the fuel cell at RT until a steady state was attained. The OCV value was recorded until the generation rate decreased to a value of $2 \mathrm{mVmin}^{-1}$. 4. The polarisation curves were recorded after the value of the OCV had been read. The current versus voltage values were recorded. The test was stopped in each case when the voltage of the fuel cell decreased to a value of $0.5 \mathrm{~V}$. A voltage decrease to below $0.5 \mathrm{~V}$ was avoided so as to prevent the alkaline electrolyte from penetrating into the cathode electrode. 5. To determine the Coulombic efficiency (CE) of the test fuel cell, the fuel cell was loaded with $1 \mathrm{M}$ pure anhydrous glucose (Oriola) in aqueous $2 \mathrm{M} \mathrm{KOH}$ electrolyte. The current vs. time was recorded with the help of the data recording pc system from the OCV value down to $0.5 \mathrm{~V}$. The $\mathrm{CE}$ value was calculated as a ratio from Equation 2 according to Ref. [18]:

$$
C E=\frac{\left(M_{w} \int I d t\right) \cdot 100 \%}{F n_{e} V_{a n} \Delta C}
$$

In Equation $2 \mathrm{M}_{\mathrm{w}}$ is the molecular weight of the fuel, $n_{e}$ is the number of transferred electrons, $V_{a n}$ is the volume of liquid in the anode $\left(=0.3 \mathrm{dm}^{3}\right), \mathrm{F}$ is the Faraday constant $(=96500 \mathrm{As} / \mathrm{mol})$ and $\Delta \mathrm{C}$ is the change of fuel concentration (Co-C). $\Delta \mathrm{C}=\mathrm{Co}$ is often used. The term (JIdt) corresponds to the integration of the recorded current versus time. The recorded electric current capacity [As] is then divided by the maximum electric yield from the initial glucose molar amount, when glucose is oxidised to gluconic acid $\left[\mathrm{C}_{6} \mathrm{H}_{12} \mathrm{O}_{7}\right]\left(\mathrm{n}=2 \mathrm{e}^{-}\right)$.

\section{Results}

Acid hydrolysis. The hydrolysis of starch reached a yield of $1 \mathrm{~g}$ of glucose per $\mathrm{g}$ of starch, when the weighted maize starch concentration was kept below $50 \mathrm{gdm}^{-3}$ according to Ref. [13]. When the maize starch concentration was increased to $200 \mathrm{gdm}^{-3}$ the glucose yield decreased to $0.24 \mathrm{~g}$ glucose per $\mathrm{g}$ of starch. The colouring effect was also very 
strong. In order to avoid the strong colouring effect and the formation of inhibitors the starch hydrolysate, which contained $24.8 \mathrm{gdm}^{-3}$ of glucose, was concentrated by evaporation. When $200 \mathrm{~g}$ of cellulose was hydrolysed according to Ref. [13], the glucose yield was $1.32 \mathrm{gdm}^{-3}$ and the colouring effect was very strong. In addition, the performance of the hydrolysate in the fuel cell was insufficient (the data are not shown here). Therefore, the cellulose hydrolysis was carried out by strong-dilute acid hydrolysis followed by autoclavation. This method resulted in $0.29 \mathrm{~g}$ glucose $/ \mathrm{g}$ cellulose from $50 \mathrm{~g}$ of weighed cellulose paper (see Table 1). In all cases only a small part of the glucose was used in the fuel. The cellulose hydrolysate had a 58\% glucose utilisation rate.

Table 1. Starch and cellulose hydrolysation results.

\begin{tabular}{|l|c|c|c|}
\hline Substrate & $\begin{array}{l}\text { Intial } \\
\mathrm{gdm}^{-3}\end{array}$ & $\begin{array}{l}\text { Glucose } \\
\mathrm{gdm}^{-3}\end{array}$ & $\begin{array}{l}\text { Yield } \\
\mathrm{g} \mathrm{g}^{-1}\end{array}$ \\
\hline Starch & 10 & 12.8 & $1.28^{*}$ \\
\hline Starch & 20 & 24.8 & $1.24^{*}$ \\
\hline Starch** & 20 & 80.0 & - \\
\hline Starch & 200 & 47.0 & 0.24 \\
\hline Cellulose & 50 & 14.6 & 0.29 \\
\hline
\end{tabular}

*) The yields are higher than weighed substrate as a result of the evaporation during the autoclavation.

**) Concentrated glucose solution by evaporation from the starch hydrolysate containing $20 \mathrm{gdm}^{-3}$ of glucose.

The fuel cell tests. In Figure 3 the measured polarisation curves with three glucose concentrations from starch acid hydrolysis, and with one glucose concentration from cellulose acid hydrolysis, are shown. The measured OCV values related to Figure 3 in respect to the concentrations of the fuels at room temperature (RT) are shown in Table 2. The average measured OCV generation rates (AMGR OCV) in each test are also presented. Glucose with a concentration of $80 \mathrm{gdm}^{-3}$ was also used, but the determination of the polarisation curve did not produce a higher current density than $0.4 \mathrm{mAcm}^{-2}$ although the OCV value was $0.678 \mathrm{~V}$. From the results shown in Fig. 3 and Table 2 it can be seen that the glucose content $24.8 \mathrm{gdm}^{-3}$ $\left(0.14\right.$ moldm $\left.^{-3}\right)$ produced the best results in the test direct-mode fuel cell. The higher concentrated glucose values indicated that the glucose has been decomposed in the concentrating. Other compounds (e.g. dissolved sulphate) also disturb the operation of the electro catalysts.

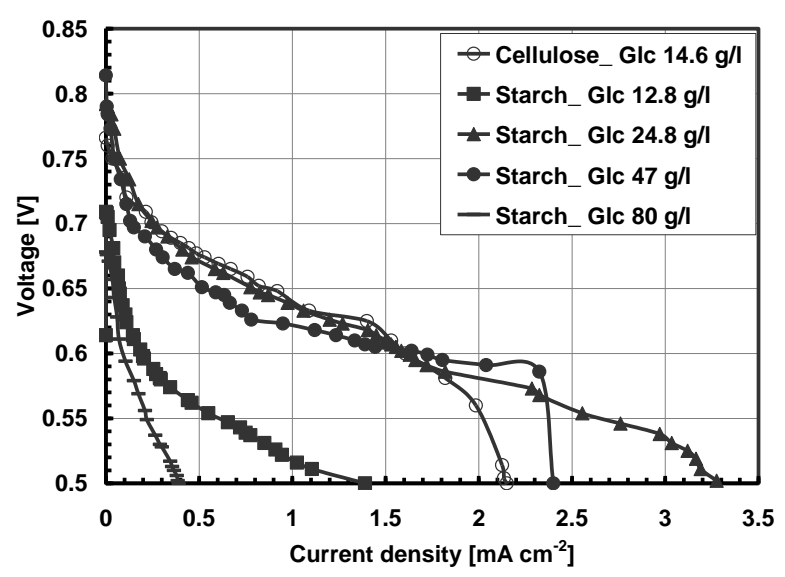

Figure. 3. Polarisation curves for glucose from hydrolysis in the direct-mode fuel cell.

Table 2. The measured OCV values and average generation rates for glucose at RT.

\begin{tabular}{|c|c|c|}
\hline $\begin{array}{c}\text { Glucose } \\
\text { concentration } \\
{\left[\mathrm{gdm}^{-3}\right]}\end{array}$ & OCV & $\begin{array}{c}\text { AMGR } \\
\text { OCV } \\
{\left[\mathrm{mV} \mathrm{min}^{-1}\right]}\end{array}$ \\
\hline From starch: & & \\
\hline 12.8 & 0.71 & 2.3 \\
\hline 24.8 & 0.792 & 6.6 \\
\hline 47 & 0.814 & 5.6 \\
\hline 80 & 0.678 & 3.8 \\
\hline From cellulose: & & \\
\hline 14.6 & 0.766 & 0.53 \\
\hline
\end{tabular}

The $14.6 \mathrm{gdm}^{-3}$ glucose concentration from the hydrolysis of cellulose produced the third best results in the test fuel cell. Concerning the rates of OCV values in each test, the test with glucose from starch in concentrations from 12.8 to $47 \mathrm{gdm}^{-3}$ generated OCV values within 40 minutes. OCV generation with $80 \mathrm{gdm}^{-3}$ glucose from starch took 75 minutes. OCV generation with $14.6 \mathrm{gdm}^{-3}$ glucose from cellulose took 130 minutes. However it was clearly indicated that the hydrolysation and the following concentrating methods have to be much improved to produce higher glucose concentrations in the hydrolysates. It was reported early on that 
pure glucose in a concentration of $1 \mathrm{M}$ provides current density values from 5 (at RT) to $8 \mathrm{mAcm}^{-2}$ (at $51^{\circ} \mathrm{C}$ ) with a voltage of $0.5 \mathrm{~V}$ $[1,2]$. Thus, the detected OCV and current density values with a lower glucose concentration in hydrolysates did not produce values equal to those reached earlier with pure glucose $[1,2]$. The current density values for pure glucose at RT and at $51{ }^{\circ} \mathrm{C}$ were found to be essentially higher than the findings in earlier reports [3-5], in which biofuel cells with starch or glucose as a fuel were provided with either a microbial culture and/or a proton-selective membrane. According to the results in this presentation, the development of the acid hydrolysis of starch and cellulose should be developed so as to be able to concentrate glucose in hydrolysates to minimum values of $1 \mathrm{M}$. However, in the concentrating step the temperature must not exceed $40{ }^{\circ} \mathrm{C}$ in order to prevent the decomposition of the glucose as described in Ref. [19].

CE of the fuel cell. The calculated maximum value of the Coulumbic efficiency (CE) with the pure glucose as a fuel according to Equation 2 is shown in Table 3.

Table 3. The calculated value for the maximum $C E$ value $\left(\mathrm{n}_{\max }=2 \mathrm{e}-\right)$ with glucose as a fuel.

\begin{tabular}{|l|c|}
\hline Parameter & Value \\
\hline $\mathrm{C}_{\mathrm{o}}$ initial concentration & $1 \mathrm{M}\left(\mathrm{M}_{\mathrm{w}}=180 \mathrm{gmol}^{-1}\right)$ \\
\hline Max. current capacity & $57900 \mathrm{As}$ \\
\hline
\end{tabular}

In the Figures 4 and 5 the recorded values for the voltage and current output of the directmode fuel cell are shown as functions of time.

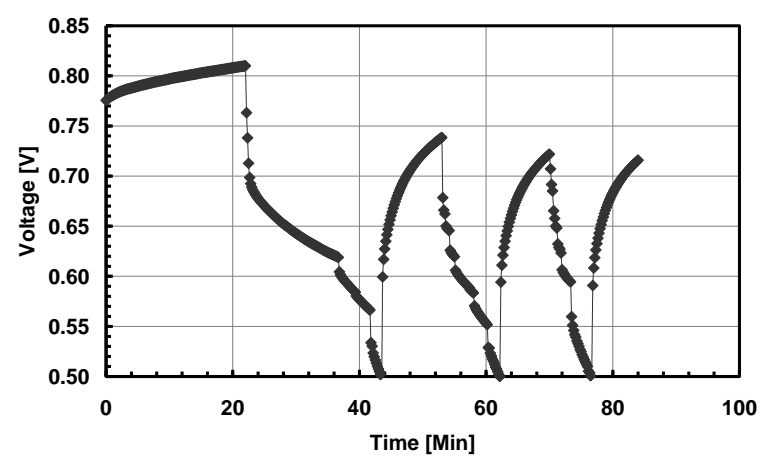

Figure. 4. Recorded voltage values of direct mode fuel cell in the tests.

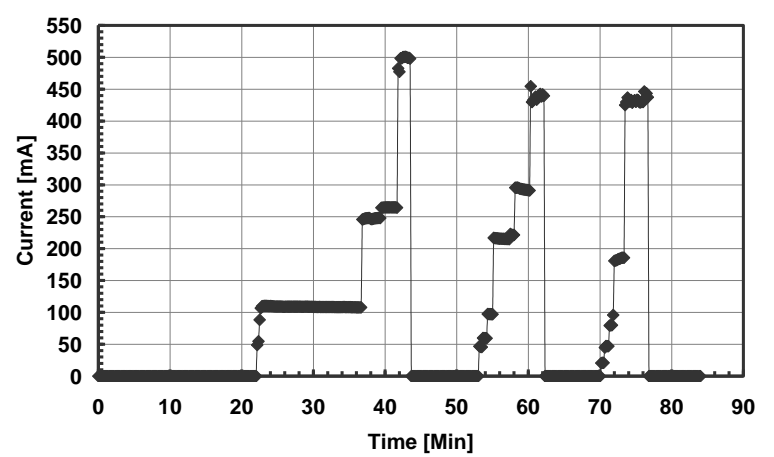

Figure. 5. The recoded current values in the fuel cell.

The current output was repeated three times as shown in Figures 4 and 5. The fuel cell voltage was dropped from the OCV value down to $0.5 \mathrm{~V}$. The generation of OCV was then followed after each discharging. The calculated CE values for each cycle and in the entire test are shown in Table 4.

Table 4. The determinated CE values as ratios to theoretical value ( $\mathrm{n}=2 \mathrm{e}$ - per molecule).

\begin{tabular}{|c|c|c|}
\hline Cycle in test & $\begin{array}{c}\text { Current } \\
\text { capacity }[\mathrm{As}]\end{array}$ & $\begin{array}{c}\text { CE } \\
{[\%]}\end{array}$ \\
\hline 1 & 225 & 0.39 \\
\hline 2 & 138 & 0.24 \\
\hline 3 & 109 & 0.19 \\
\hline$\sum 1$ to 3 & 473 & 0.82 \\
\hline
\end{tabular}

It is shown in Table 4 that the $\mathrm{CE}$ values are very low. One reason for the low $\mathrm{CE}$ values is that the voltage drop in each tests stopped at a value of $0.5 \mathrm{~V}$ and unusable glucose remained that was usable for the electrochemical oxidation. Therefore it is also assumed that in the electro-chemical oxidising of the glucose molecule the maximum yield of the electrons was two. It can be seen from Table 4 that the value of $\mathrm{CE}$ decreased by $38.5 \%$ in the second cycle from the value in the first cycle, and by $20.8 \%$ in the third cycle from the value in the second cycle. According to the tests in the fuel cell, the development of the direct-mode fuel cell also includes selecting and searching for more effective catalyst materials. 


\section{Summary}

Starch and cellulose are interesting candidates as fuel sources for fuel cells, because they need fewer processing steps compared to other biofuels, such as bio-ethanol, before being supplied to the fuel cell. In this study glucose was produced by acid hydrolysis from starch and cellulose. The glucose concentrations in the hydrolysates were found to be too low to be able to produce equal power densities (from 2.5 to $4 \mathrm{mWcm}^{-2}$ ) as were earlier reported with pure glucose of a $1 \mathrm{M}$ concentration. Thus the concentration of glucose has to be higher in the hydrolysates. The research should also concentrate on the development of more effective and active catalyst materials for the oxidation of glucose, because both the current density and the Coulombic efficiency (CE) values were found to be low in the test fuel cell. The low CE values indicate that the maximum yield of transferred electrons in the electro-chemical oxidation of the glucose molecule was two. However, starch and cellulose are interesting fuel sources for the low-temperature fuel cells. Cellulose is an especially interesting candidate for the production of the electric power, because it is not taken from the raw materials used in food production.

\section{Acknowledgements}

This work is supported by the Finnish Funding Agency for Technology and Innovation (TEKES) and by Finnish partners (UPM, St-1 Biofuels, Diarc, Hydrocell and the Finnish Research Centre (VTT)). Thanks are also given to the research team in the ongoing COST Action 543.

\section{References}

[1] Spets J.-P., Kiros Y., Kuosa M. A., Rantanen J., Sallinen J., Lampinen M. J., Saari K. Open Fuel Cells J., 1(2008)1-3.

[2] Spets, J.-P., Kiros. Y., Kuosa M. A., Rantanen J., Lampinen M. J., Saari K. 2009. In: The $7^{\text {th }}$ Spring Meeting of the Int. Soc. of
Electrochem. Szczyrk, Poland. March $22^{\text {nd }}$ to $25^{\text {th }}, 2009$.

[3] Rabaey K. and Verstraete W. Trends in Biotech. 23 (2005) 291-298.

[4] Stetten, F. von, Kerzenmacher S., Lorenz A., Chokkalingam V., Miyakava N., Zengerle R. and Ducree J. A. 2006. In: MEMS. Jan 2226. 934-937.

[5] Niessen J., Schröder U. and Scholz F. Elect. Chem. Comm. 6 (2004) 955-958.

[6] Verma A. and Basu S. J. of Pow. Sourc. 174 (2007) 180-185.

[7] Verma A. and Basu S. J. of Pow. Sourc. 145 (2005) 282-285.

[8] Li J., Moore C. and Kohl P.A. J. of Pow. Sourc. 138 (2004) 211-215.

[9] Yao S. J., Appleby A. J., Geisel A., Cash H. R. and Wolfson Jr. S. K. Nature 224 (1969) 921-922.

[10] McGinley J., McHale F. N., Hughes P., Reid C. N. and McHale A. P. Biotech. Letters. 26 (2004) 1771-1776.

[11] Kelly M. J., Ingersoll D., Steen W. A., Cocker E. N., Abraham I. C. and Miller J. E. Abs. 736, 205 ${ }^{\text {th }}$ Meeting. (C2004 The Electr.chem. Soc. Inc..

[12] Dhepe P. L. and Fukuoka A. Catal. Surv Asia 11(2007) 186-191.

[13] Choi C. N. and Mathews A. P. Bioresourc. Techn. 58 (1996) 101-106.

[14] Virtanen S. 2006. Hydrolysis of

Lignocellulose. Litterature report. Lappeenranta TU. Finland. 24 pp.

[15] Almeida J. RM., Modig T., Petersson A., Hähn-Hägerdal B., Lidén G. and GorwaGrauslund M. F. J. Chem Technol Biotechnol 82 (2007) Pp. 340-349.

[16] Alve H. M.Sc. thesis. 2007. Lappeenranta TU. Finland. 91 pp. + Apps.

[17] Spets J.-P., Kiros Y., Rantanen J., Sallinen J., Lampinen M. J., Noponen T. and Saari K. ID: 2008NTNE-300. In: Nanotech Northern Europe. Copenhagen $23^{\text {rd }}$ to $25^{\text {th }}$ September 2008.

[18] Logan B. E. Microbial fuel cells. 2008.

Wiley -Interscience. 198 pp.

[19] Virtanen S. Hydrolysis of Lignocellulose with Concentrated Sulphuric Acid. 2006. Laboratory work. Lappeenranta TU. Finland. $17 \mathrm{pp}$. 